\title{
Toxicity, biochemical and clastogenic response of chlorpyrifos and carbendazim in milkfish Chanos chanos
}

\author{
L. Palanikumar • A. K. Kumaraguru • \\ C. M. Ramakritinan $\cdot$ M. Anand
}

Received: 2 May 2012/Revised: 11 January 2013/Accepted: 13 March 2013/Published online: 17 April 2013

(C) Islamic Azad University (IAU) 2013

\begin{abstract}
Carbendazim and Chlorpyrifos are some of the most widespread environmental contaminants of major concern to human and animal reproductive health. Acute toxicity test results for pesticides were evaluated by the Probit analysis method and $96 \mathrm{~h} \mathrm{LC}_{50}$ values for $C$. chanos exposed to chlorpyrifos was 3.73 and $11.5 \mu \mathrm{g} \mathrm{l^{-1 }}$ for carbendazim. Chlorpyrifos and carbendazim significantly decreased total protein, catalase, glutathione S-transferase and acetyl choline esterase and induced lipid peroxidation. Maximum effects of protein, catalase, lipid peroxidation, acetyl choline esterase and glutathione s-transferase were obtained in response to $23.68 \mu \mathrm{g} \mathrm{l}^{-1}$ of chlorpyrifos and $43.68 \mu \mathrm{g} \mathrm{l}^{-1}$ of carbendazim. Micronuclei assay results have shown increased abnormality with increasing doses of chlorpyrifos and carbendazim. Maximum increasing in micronuclei was observed in chlorpyrifos exposed C. chanos. This study showed that chlorpyrifos and carbendazim induced alterations in the activity of antioxidant enzymes and could induce clastogenicity.
\end{abstract}

Keywords Antioxidants - Biochemical effects - Lethal concentration $\cdot$ Clastogenicity $\cdot$ Toxicity

L. Palanikumar $(\bowtie)$ A A. K. Kumaraguru

C. M. Ramakritinan - M. Anand

Department of Marine and Coastal Studies, School of Energy,

Environment and Natural Resources, Madurai Kamaraj

University, Madurai 625 021, India

e-mail: palanikumarl@gmail.com

Present Address:

L. Palanikumar

Anna University, Chennai 600025, India

\section{Introduction}

Pollution of aquatic ecosystem by chemicals used in industry and agricultural is increasing day by day. Pesticides are extensively used to protect agricultural crops against the damages caused by pests. Pesticides are released intentionally into the environment and, through various processes, contaminate the environment. Three of the main classes of pesticides that pose a serious problem are organochlorines, organophosphates and carbamates (Dyk and Pletschke 2011). The extensive use of pesticides, insecticides, herbicides and fungicides is being promoted by Government of India to enhance the crop production to meet the demand of the growing population (Binukumari and Subhisha 2010).

Extensive use of pesticides in agro ecosystem has resulted in global contamination of the environment. Only $0.1 \%$ of the applied pesticides reach the target pests and the remaining $99.9 \%$ find their way to different components of the environment (Tripathi and Shasmal 2011). Chlorpyrifos is a widely used organophosphate pesticide, second largest selling in India and used for more than a decade to control pests on cotton, paddy fields, pasture and vegetable crops (Rao et al. 2003). Chlorpyrifos is extensively used which may increase the load to aquatic environment, causing adverse effects on non-target fish. Treatment of organophosphate to fish inhibits activities of several enzymes, such as glucose-6-phosphatase, acid and alkaline phosphatases, lipid peroxidation, acetylcholinesterase, catalase, glutathione s-transferase and cytochrome oxidase (Monteiro et al. 2006; Yonar and Sakin 2011). Chlorpyrifos (O,O-diethyl O-3,5,6-trichloro-2-pyridyl phosphorothioate) is a broad-spectrum organophosphate pesticide used heavily throughout the world for agricultural and domestic purposes. Srivastava and Singh (2001) documented seasonal variation in the toxicity of organophosphate to Channa punctatus. Chindah et al. (2004) studied the 
toxicity of chlorpyrifos in Tilapia guineensis. Similarly, Gul (2005) investigated acute toxicity of chlorpyrifos for larvae of Oreochromis niloticus. Pandey et al. (2005) reported the toxicity of malathion to C. punctatus. Tripathi and Shasmal (2011) reported the toxicity of chlorpyrifos to Heteropneustes fossilis. Malathion has been reported to increase the protein content in the kidney of Clarias batrachus during the first week and thereafter a gradual decrease in the protein content was observed in the later periods of exposure (Khare et al. 2000). It also decreased the protein content in gobiid fish (Venkataramana et al. 2006).

Carbendazim (methyl-2-benzimidazole carbamate, $\mathrm{MBC}$ ), a metabolite of benomyl is one of the most widespread environmental contaminants of major concern to human and animal reproductive health (Aired 2005). MBC causes changes in chromosome number (aneuploidy) both in vitro and in vivo (in somatic cells and germ cells) as a result of its interference with mitotic spindle proteins. The mechanism by which aneuploidy is induced by carbendazim is well understood and consists of inhibition of the polymerization of tubulin, the protein that is essential for the segregation of the chromosomes during cell division. Chlorpyrifos and carbendazim are believed to affect hormone function and are included by the European Commission in the priority list of endocrine disruptors (Ferreira et al. 2008). The micronucleus (MN) assay is another useful and popular technique for showing clastogenic and aneugenic effect (Norppa and Falck 2003) and has been extensively used in situ (Ali et al. 2009).

Fish are often used as sentinel organism for ecotoxicological studies because they play a number of roles in the trophic web, accumulate toxic substances and respond to low concentration of mutagens (Cavas and Ergene-Gozukara 2005). Therefore, the use of fish biomarkers as indices of the effects of pollution, are of increasing importance and can permit early detection of aquatic environmental problems (Van Der Oost et al. 2003).

The milkfish, Chanos chanos (Forsskal 1775) is the most important tropical marine fish in aquaculture. Milkfish occurs near continental shelves and around oceanic islands throughout the tropical Indo-Pacific. The milkfish has been the subject of toxicity studies (Magesh and Kumaraguru 2006; Palanikumar et al. 2012a, 2012b). Although toxic and genotoxic effect of chlorpyrifos and carbendazim in some freshwater and marine fish were studied earlier (e.g. Ali et al. 2009; Sharbide et al. 2011), the clastogenic and aneugenic effects of chlorpyrifos and carbendazim on tropical milkfish C. chanos is a rare topic.

Therefore, the present study investigates the acute toxicity, clastogenic and biochemical response of chlorpyrifos and carbendazim using acetylcholine esterase (AchE), catalase (CAT), glutathione S-transferase (GST), lipid peroxidation (LPO) and reduced glutathione (GSH) in liver tissues and micronuclei (MN) assay were carried out in whole blood of Chanos chanos (Forskkal) exposed in vivo. The study has been approved by Institutional Ethical Committee in accordance with the ethical standards provided by the Department of Marine and Coastal Studies, Madurai Kamaraj University, India.

\section{Materials and methods}

\section{Experimental animals}

Healthy specimens of a teleostean fish $C$. chanos (average size and weight $3.1 \pm 0.3 \mathrm{~cm} ; 3.5 \pm 1.2 \mathrm{gm}$ ) were collected from Pamban coasts (Lat $09^{\circ} 16.26^{\prime} \mathrm{N}$ and Lon $079^{\circ} 12.88^{\prime} \mathrm{E}$ ), Gulf of Mannar. Initial disinfection treatment was carried out using benzyl konium chloride $\left(1 \mathrm{mg} \mathrm{l}^{-1}\right)$ for $1 \mathrm{~h}$ and $\mathrm{KMnO}_{4}$ solution $\left(1 \mathrm{mg} \mathrm{l}^{-1}\right)$ for $1 \mathrm{~h}$ and then healthy individuals were separated, acclimatized for 10 days in large glass aquaria containing aged, filtered seawater (calcium hardness $364.5 \mathrm{mg} \mathrm{l}^{-1}$, magnesium hardness $1312.0 \mathrm{mg} \mathrm{l}^{-1}$, Dissolved oxygen $6.10 \mathrm{mg} \mathrm{l}^{-1}$, silicates $5.64 \mu \mathrm{g}^{-1}$, in-organic phosphate $2.12 \mathrm{~g} \mathrm{l}^{-1}$, nitrite-nitrogen $1.23 \mu \mathrm{mol}^{-1}$, nitrate-nitrogen $3.90 \mathrm{mmol}^{-1}$ and ammonia $0.10 \mu \mathrm{g} \mathrm{l^{-1 }}$ ). During this period, the fishes were fed on live brine shrimp (Artemia sp) nauplii (Palanikumar et al. 2012b) and starved $24 \mathrm{~h}$ prior to and during the experiment.

\section{Experimental design}

The renewal test system was conducted with $60 \%$ volume replacement every $48 \mathrm{~h}$ : typically, the volume of test water replacement is about $80 \%$ for $24 \mathrm{~h}$ (Environment Canada 1998). ASTM (1997) recommends that renewals be done by replacing nearly all of the test solution and US EPA (1994) recommends that test organisms be exposed to a fresh solution either by transferring the test organisms from one test chamber to another chamber or by replacing all or a portion of solution in the same test chambers. Due to the above mentioned stressful approach to fish, and to lessen disturbance to the exposed fish, we replaced the exposure water at a lesser frequency rate and volume as suggested by Welsh et al. (2008).

The renewal chambers were aerated throughout the test duration. Prior to test initiation or toxicant renewal, exposure waters in the 20-L buckets were well aerated for approximately $24 \mathrm{~h}$ (Welsh et al. 2008).

Determination of acute concentrations of carbendazim and chlorpyrifos $\left(\mathrm{LC}_{50}\right)$

The acute toxicity bioassay test procedure based on standard methods was conducted to determine the $\mathrm{LC}_{50^{-}}-96 \mathrm{~h}$ 
values of carbendazim and chlorpyrifos (Sprague 1973; OECD 1993; APHA/AWWA/WEF 1998). The technicalgrade chlorpyrifos (20\% EC) with trade name Trickel (Excel crop care Ltd, Mumbai, India) and carbendazim (97\% purity, Sigma-Aldrich, USA) was used in the present study. A set of ten fishes was randomly exposed to ten target concentration levels (in logarithmic scale) of each pesticide compound to obtain the $\mathrm{LC}_{50}-96 \mathrm{~h}$ values of the each test chemical for the species. Oxygenation of the test solution was provided with the help of aerators. Preliminary range finding tests was performed and definitive range concentrations were chosen, i.e., 1.48, 2.96, 5.92, 11.84 and $23.68 \mu \mathrm{g}^{-1}$ for chlorpyrifos and 3.04, 6.08, $12.17,23.34$ and $48.68 \mu \mathrm{g}^{-1}$ for carbendazim. The concentrations dissolved were estimated using pooled test medium. JOEL data system was used for chlorpyrifos and carbendazim analysis. The recoveries of spiked standards ranged from 56 to $98 \%$.

The range of concentrations present in the test medium was $1.38,2.15,4.53,9.27$ and $18.79 \mu \mathrm{g} \mathrm{l}^{-1}$ for chlorpyrifos and 2.85, 5.45, 10.97, 20.17 and $45.31 \mu \mathrm{g} \mathrm{l}^{-1}$ for carbendazim, respectively. $0.05 \%$ acetone and seawater was were maintained as negative control. In control medium, the concentrations of chlorpyrifos and carbendazim were nil. The experiments were carried out for a period of $96 \mathrm{~h}$ under renewal test system for four times and mortality of organisms were noted at an interval of $24 \mathrm{~h}$.

\section{Estimation of biomarkers}

After the stipulated periods of treatment $(96 \mathrm{~h})$, the live fish were killed and liver tissues were isolated in ice-cold condition for further studies. Pooled samples were used for the estimation of biomarkers.

\section{Protein}

The protein content in liver tissues was determined by the method described by Lowry et al. (1951) and Palanikumar et al. (2012b) using bovine serum albumin (BSA) as a standard.

\section{Lipid peroxidation}

Liver tissues were analyzed according to Vieira et al. (2008) with slight modifications suggested by Palanikumar et al. (2012b). Lipid peroxidation was measured by the generation of thiobarbituric acid reactive species and quantified in terms of malondialdehyde equivalents. Its absorbance was measured at $532 \mathrm{~nm}$ with Systronics make double beam UV-visible spectrophotometer Model 2201 series. Each sample was run in triplicate.
Catalase

Enzymatic activity was evaluated in liver tissues of fish exposed to acute concentrations following the method described by Bainy et al. (1996) with slight modifications suggested by Vieira et al. (2008). CAT activity was measured by the rate of hydrogen peroxide $\left(\mathrm{H}_{2} \mathrm{O}_{2}\right)$ decomposition at $240 \mathrm{~nm}$ (Beutler 1982) with Systronics make double beam UV-visible spectrophotometer Model 2201 series. Each sample was run in triplicate.

\section{Acetyl choline esterase}

The activity of AChE in liver tissues of fish was assayed according to the method of Vieira et al. (2008) with slight modifications suggested by Palanikumar et al. 2012b. The reaction mixture $(3 \mathrm{ml})$ contained sodium phosphate buffer (50 ml, pH 7.5), 5, 5, dithiobis-(nitrobenzoic acid), (DTNB, $0.5 \mathrm{mM}$ prepared in $10 \mathrm{mM}$ phosphate buffer, $\mathrm{pH}$ 7.5 and $15 \mathrm{mg}$ sodium bicarbonate added per $10 \mathrm{ml}$ of solution), the substrate acetylthiocholine iodide (ATI, $0.5 \mathrm{mM}$ ) and enzyme protein (50-100 mg). For assays, the concentration of the substrate, DTNB and enzyme protein in reaction mixture were chosen so as to give maximal reaction rate. The increase in absorbance was recorded at $412 \mathrm{~nm}$ and $28^{\circ} \mathrm{C}$ for $3 \mathrm{~min}$ in a Systronics make double beam UV-visible spectrophotometer Model 2201 series. Measurement was made in triplicate for each tissue homogenate. Simultaneously two blanks were also used: one containing phosphate buffer, DTNB, and ATI, but not enzyme protein, to determine hydrolysis of ATI, and the second containing phosphate buffer, DTNB and enzyme protein, but not substrate (ATI), to correct for any nonAChE dependent formation of thio nitro benzoic acid. The blank readings were subtracted from the experimental absorbance increase per min. One unit of enzyme activity has been defined as the amount of enzyme required to catalyze the hydrolysis of one micromole of the ATI into product per minute under specified experimental conditions. The specific activity of enzyme is expressed as units of enzyme activity per mg protein. The extinction coefficient of the yellow anion $\left(1.36 \times 10^{4} \mathrm{M}^{-1} \mathrm{~cm}^{-1}\right)$ was employed for calculating the enzyme activity (Ellman et al. 1961).

\section{Glutathione S transferase}

Glutathione $\mathrm{S}$ transferase activity in liver tissues of fish was estimated according to the method of Vieira et al. (2008). Reaction mixtures contained $4.95 \mathrm{ml}$ phosphate buffer (0.1 M, at pH 6.5): $0.9 \mathrm{ml} \mathrm{GSH} \mathrm{(10} \mathrm{mM):0.15} \mathrm{ml}$ CDNB $(60 \mathrm{mM})$. One $\mathrm{ml}$ of reaction mixture was added to $0.5 \mathrm{ml}$ of the sample, with the final concentration of with 
Table 1 Median lethal concentration $\left(\mathrm{LC}_{50}\right)$ values of carbendazim and chlorpyrifos to milkfish $C$. chanos $(n=4)(\mathrm{Mean} \pm \mathrm{SD})$

\begin{tabular}{lllll}
\hline Toxicants & \multicolumn{2}{l}{$\mathrm{LC}_{50}\left(\mu \mathrm{g} \mathrm{1^{-1 }}\right)$} & & \multicolumn{2}{c}{$R^{2}$ value } \\
\cline { 2 - 5 } & $24 \mathrm{~h}$ & $48 \mathrm{~h}$ & $72 \mathrm{~h}$ & $96 \mathrm{~h}$ \\
\hline Chlorpyrifos & $36.81 \pm 5.47$ & $23.79 \pm 10.52$ & $12.23 \pm 0.40$ & $3.56 \pm 0.13$ \\
Carbendazim & $196.1 \pm 12.59$ & $106.9 \pm 32.96$ & $18.76 \pm 3.12$ & $13.3 \pm 0.36$ \\
\hline
\end{tabular}

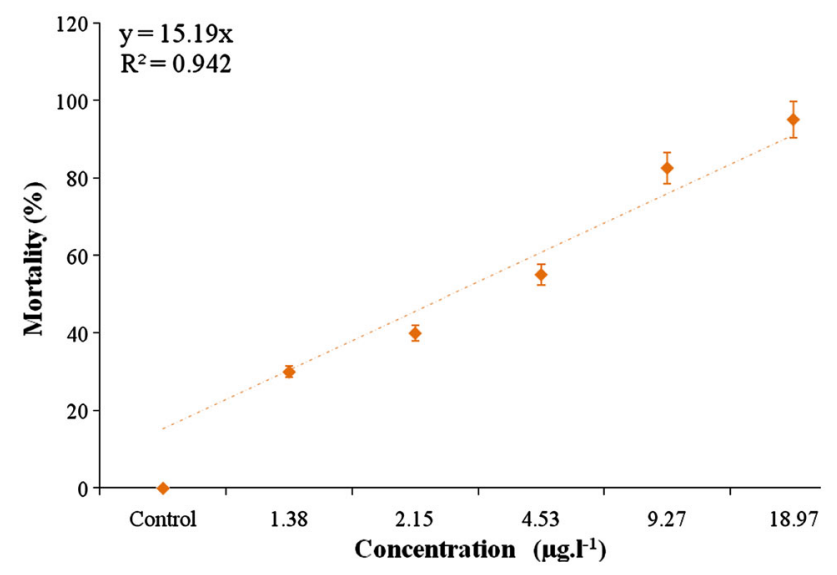

Fig. 1 Percentage mortality of milkfish C. chanos exposed to chlorpyrifos at $96 \mathrm{~h}$

the final concentration of $1 \mathrm{mM} \mathrm{GSH}$ and $1 \mathrm{mM}$ CDNB in the assay. The activity rate of GST was measured as the change in $\mathrm{OD} / \mathrm{min}$ at $340 \mathrm{~nm}$ (ext. coefft. $9,600 \mathrm{M}^{-1}$ $\mathrm{cm}^{-1}$ ) in a Systronics make double beam UV-visible spectrophotometer Model 2201 series and expressed as nmol $\min ^{-1} \mathrm{mg}$ protein ${ }^{-1}$.

\section{Micronucleus assay}

The slides were prepared by smearing one drop of blood on clean microscopic slides, fixed in methanol for $10 \mathrm{~min}$ and left to air-dry at room temperature and finally stained with $5 \%$ Giemsa in Sorenson buffer ( $\mathrm{pH}$ 6.9) for 20 min. A total of 1,000 erythrocytes were examined for each specimen under the light microscope. For the scoring of micronuclei, the following criteria were adopted from Fenech et al. (2003): the diameter of the micronuclei (MN) should be less than one-third of the main nucleus. MN should be separated from or marginally overlap with main nucleus as long as there is clear identification of the nuclear boundary. MN should have similar staining as the main nucleus.

\section{Statistical analysis}

Median lethal concentration $\left(\mathrm{LC}_{50}\right)$ values were calculated for 24-, 48-, 72- and 96-h time points for each test series

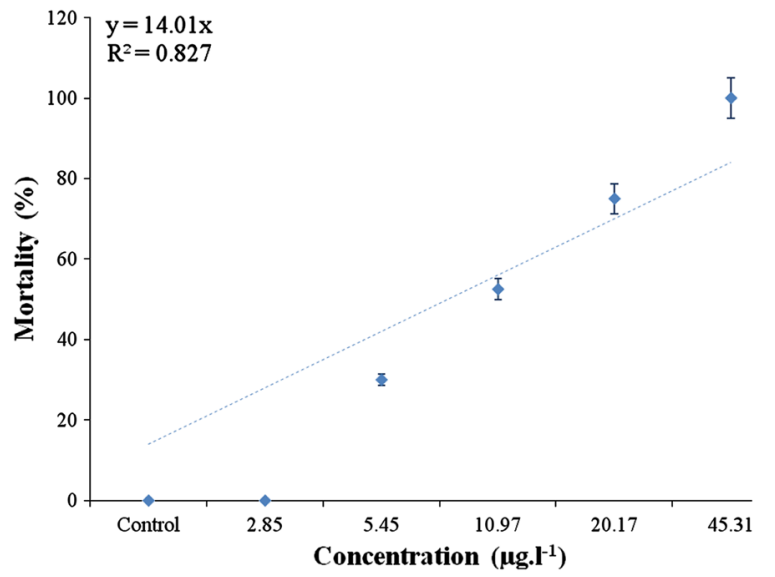

Fig. 2 Percentage mortality of milkfish C. chanos exposed to carbendazim at $96 \mathrm{~h}$

using the Probit analysis software (Finney 1971; US EPA 1994). The differences in biomarkers in comparison with control animals for each pesticide were assessed by one way analysis of variance (ANOVA). Dunnett's test was employed to compare the significant difference between control and different exposure concentrations. Analysis of variance was carried out using Graph Pad prism software version 5.0.

\section{Results and discussion}

Influence of acetone

Acetone $(0.05 \%)$ was used as a solvent in the present study. Control groups received equal volume of acetone. The results showed that the acute toxicity and biomarker enzyme activity were not affected by acetone.

\section{Acute toxicity}

The calculated 24-, 48-, 72- and 96-h acute $\mathrm{LC}_{50}$ values and their respective $95 \%$ confidence limits for chlorpyrifos and carbendazim exposed to fingerlings of $C$. chanos under renewal test system are shown in Table 1 . The mean $96 \mathrm{~h}$ $\mathrm{LC}_{50}$ values were $3.56 \pm 0.13 \mu \mathrm{g}^{-1}$ for chlorpyrifos and $13.3 \pm 0.36 \mu \mathrm{g} \mathrm{l}^{-1}$ for carbendazim. More immobilized 
Table 2 Protein content in milkfish $C$. chanos exposed to acute concentrations of carbendazim and chlorpyrifos after $96 \mathrm{~h}( \pm \mathrm{SD})(n=3)$

\begin{tabular}{|c|c|c|c|c|c|c|}
\hline \multirow{2}{*}{$\frac{\text { Toxicants }}{\text { Carbendazim }}$} & \multicolumn{6}{|c|}{ Concentration $\left(\mu \mathrm{g}^{-1}\right)$} \\
\hline & Control & 2.85 & 5.45 & 10.97 & 20.17 & 45.31 \\
\hline Protein $\left(\mathrm{mg} \mathrm{g}^{-1}\right.$ tissue $)$ & $11.75 \pm 0.28$ & $10.50 \pm 0.27$ & $9.65 \pm 0.30$ & $8.89 \pm 0.12$ & $6.55 \pm 0.28$ & $4.60 \pm 0.23$ \\
\hline Chlorpyrifos & Control & 1.38 & 2.15 & 4.53 & 9.27 & 18.97 \\
\hline Protein ( $\mathrm{mg} \mathrm{g}^{-1}$ tissue) & $12.56 \pm 0.46$ & $10.71 \pm 0.38$ & $9.75 \pm 0.14$ & $7.60 \pm 0.27$ & $6.23 \pm 0.17$ & $5.49 \pm 0.11$ \\
\hline
\end{tabular}

response was observed in higher concentrations of both pesticides when compared with lower concentrations. When introduced to higher concentrations, fish showed erratic swimming movement. No mortality was observed in th control and solvent control groups. Percentage mortality of C. chanos exposed to different acute concentrations of chlorpyrifos and carbendazim is shown in Figs. 1 and 2. The mortality of fish increased with increasing concentrations of chlorpyrifos and carbendazim as well as experimental duration. The fish under pesticide stress showed symptoms of dullness and erratic swimming.

\section{Biomarkers}

\section{Protein}

The mean protein contents were $11.75 \pm 0.28$ and $12.56 \pm 0.22 \mathrm{mg} \mathrm{g}^{-1}$ tissue in control fish which significantly reduced $(P<0.01)$ in the highest concentrations of pesticides, i.e., $4.60 \pm 0.23 \mathrm{mg} \mathrm{g}^{-1}$ tissue in $18.79 \mu \mathrm{g} \mathrm{l}^{-1}$ chlorpyrifos and $5.49 \pm 0.25 \mathrm{mg} \mathrm{g}^{-1}$ tissue in $45.31 \mu \mathrm{g} \mathrm{l}^{-1}$ carbendazim, respectively (Table 2). Maximum reduction in total protein content was observed in chlorpyrifos-exposed fish.

\section{Lipid peroxidation}

Significant differences $(P<0.05$ and $P<0.01)$ were detected between treatment and control fish. LPO level in C. chanos exposed to different concentrations of chlorpyrifos and carbendazim was shown in Fig. 3a, b. Significant increase $(P<0.05$ and $P<0.01)$ in LPO level was observed in chlorpyrifos- and carbendazim-exposed fish when compared with control fish. Maximum increase in LPO level was observed in the highest concentration, i.e., $45.31 \mu \mathrm{g} 1^{-1}$ of carbendazim.

\section{Catalase}

CAT activity in $C$. chanos was decreased with increasing concentrations of chlorpyrifos and carbendazim (Fig. 4a, b). Significant decrease $(P<0.05$ and $P<0.01)$ was observed between control and treatment exposed fish.
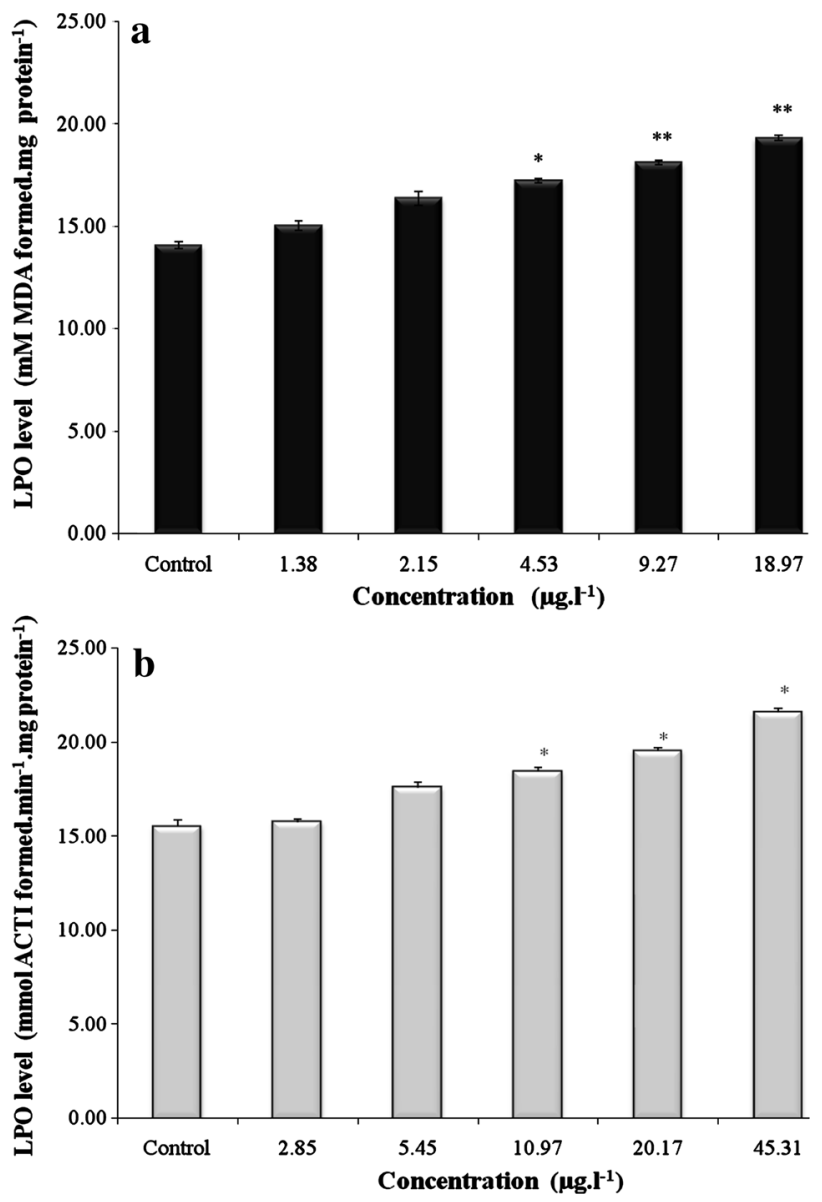

Fig. 3 a Effect of chlorpyrifos on lipid peroxidation in liver of $C$. chanos. Values are mean $\pm \mathrm{SD}(n=3)$. ${ }^{*} P<0.05$, $* * P<0.01$ statistically different from control. b Effect of carbendazim on lipid peroxidation in liver of $C$. chanos. Values are mean $\pm \mathrm{SD}(n=3)$. $* P<0.05, * * P<0.01$ statistically different from control

Maximum decrease in catalase activity was observed in chlorpyrifos-exposed fish.

\section{Acetylcholine esterase}

Similar to CAT activity, AchE level was decreased with increasing concentrations of chlorpyrifos and carbendazim (Fig. 5a, b). Significant decrease $(P<0.05$ and $P<0.01)$ was observed between control and treated fish. Maximum decrease in AchE activity was observed in chlorpyrifos-exposed fish. 

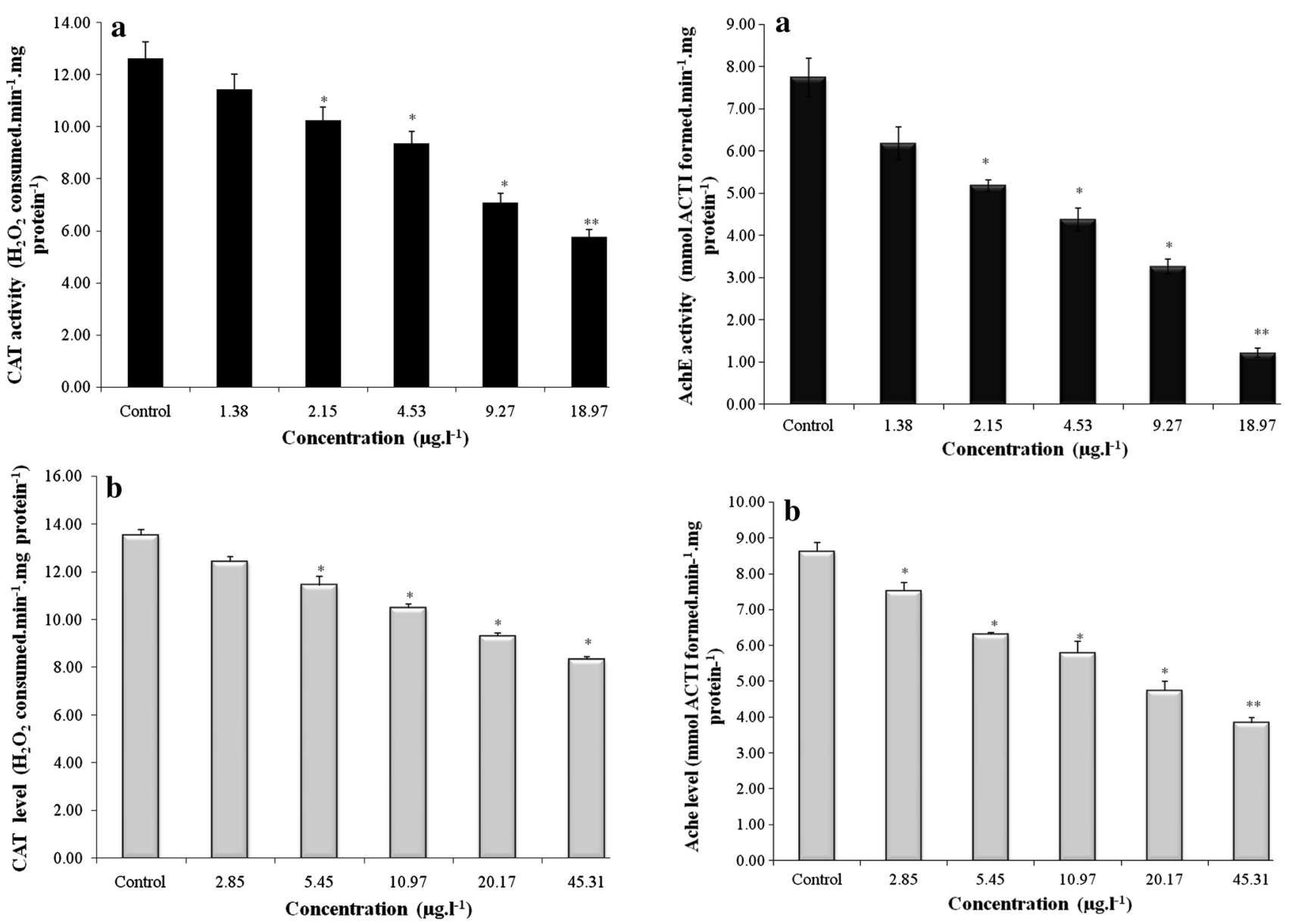

Fig. 4 a Effect of chlorpyrifos on catalase level in liver of $C$. chanos. Values are mean $\pm \mathrm{SD}(n=3) . * P<0.05$, $* * P<0.01$ statistically different from control. b Effect of carbendazim on catalase level in liver of $C$. chanos. Values are mean $\pm \mathrm{SD}(n=3) .{ }^{*} P<0.05$, $* * P<0.01$ statistically different from control

\section{Glutathione S transferase}

Significant decrease $(P<0.05$ and $P<0.01)$ in GST activity was observed in chlorpyrifos- and carbendazimexposed fish when compared with control fish (Fig. 6a, b). Maximum decrease in GST activity was observed in carbendazim-treated fish.

\section{Micronucleus test}

Micronuclei formation (Fig. 7) in erythrocytes of $C$. chanos at different concentrations after 96-h time period are summarized in Table 3. There was significant induction of MN with increasing concentrations of both the pesticides. Maximum of $21.00 \pm 0.89 \mathrm{MN}$ cells were observed in chlorpyrifos-exposed fish. MN cells increase with increasing concentrations of chlorpyrifos and carbendazim.

Chemical pesticides are well recognized as an economic approach to controlling pests; at the same time, such

Fig. 5 a Effect of chlorpyrifos on AchE activity in liver of $C$. chanos. Values are mean $\pm \mathrm{SD}(n=3) . * P<0.05, * * P<0.01$ statistically different from control. b Effect of carbendazim on AchE activity in liver of $C$. chanos. Values are mean $\pm \mathrm{SD}(n=3)$. $* P<0.05$, $* * P<0.01$ statistically different from control

chemicals are highly toxic to other species in the environment. Now there is growing concern worldwide over the indiscriminate use of such chemicals that results in environmental pollution and toxicity risk to non-target organisms (Venkateswara Rao 2004). The study of pesticide-induced effects on various antioxidants in fish and other aquatic organisms would provide relevant information about the toxicological consequences of pesticides in agriculture (Kavitha and Rao 2007).

Commonly used sampling techniques, such as taking integrated water samples from various depths and filtering, may result in an under estimation of the likely exposure faced by multi-life-stage organisms. Many pesticides adsorb particulates, accumulate in sediments and bioaccumulate in planktonic organisms to higher concentrations than the dissolved levels in the water column (Lakra and Nagpure 2009). In particular, pesticides drain into water bodies and can hamper fish health (Tripathi and Shasmal 2011). 

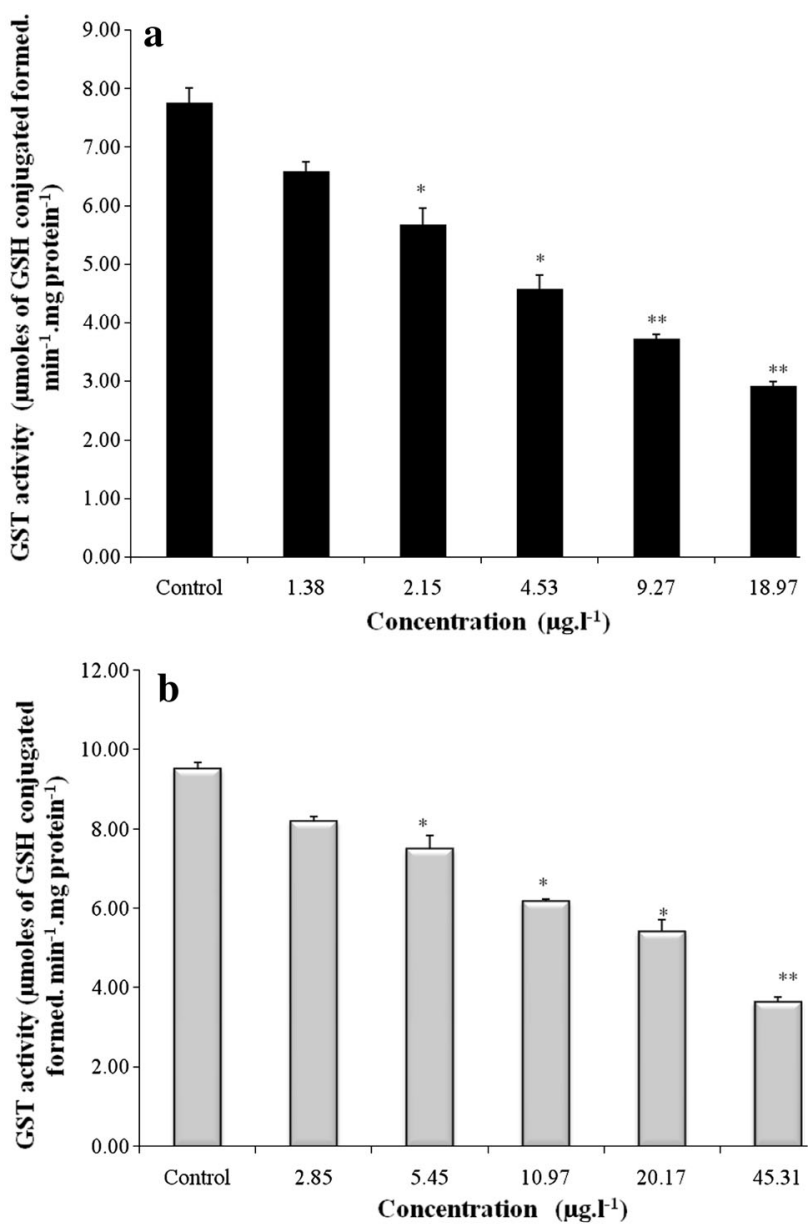

Fig. 6 a Effect of chlorpyrifos on GST activity in liver of $C$. chanos. Values are mean $\pm \mathrm{SD}(n=3) . * P<0.05, * * P<0.01$ statistically different from control. b Effect of carbendazim on GST activity in liver of $C$. chanos. Values are mean $\pm \mathrm{SD}(n=3)$. $* P<0.05$, $* * P<0.01$ statistically different from control

The acute toxicity of chlorpyrifos and carbendazim was evaluated under renewal test system. Chlorpyrifos is found to be more toxic when compared with carbendazim. The variations in $\mathrm{LC}_{50}$ values of the current study when compared with that of several others (Ali et al. 2009; Rico et al. 2011) may be due to environmental factors and regional influence (Magesh and Kumaraguru 2006). Reduction in protein content appears to be due to the inhibition of protein synthesis or its increased degradation in the presence of the organophosphate pesticide (Tilak et al. 2005; Tripathi and Shasmal 2011). The fish under pesticide stress showed symptoms of dullness and erratic swimming as observed in case of Oreochromis mossambicus exposed to organophosphorous insecticide (RPR-II) (Venteshwara Rao 2006).

The organophosphate pesticide compounds generally exhibit their effects by inhibition of AChE, which leads to accumulation of the neurotransmitter acetylcholine in
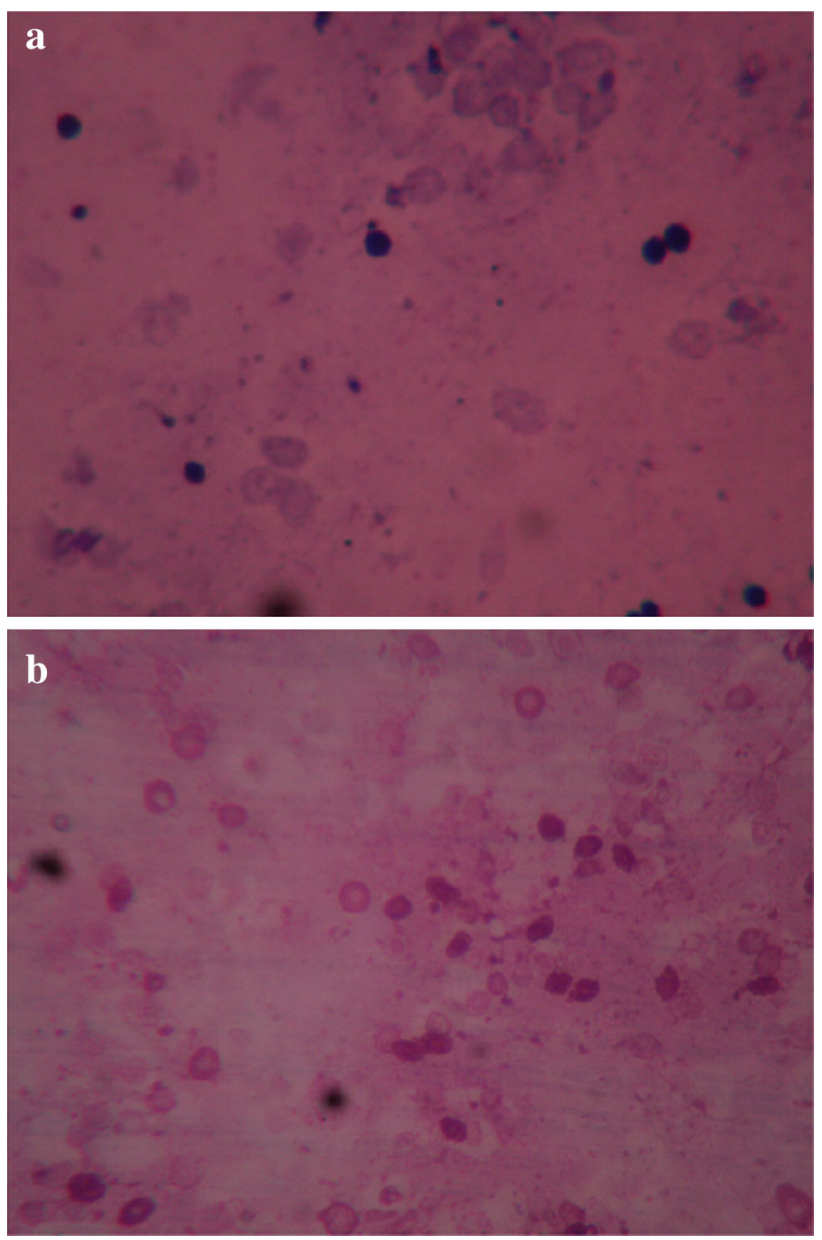

Fig. 7 Formation of micronuclei in erythrocytes of $C$. chanos at a $20.17 \mu \mathrm{g} \mathrm{ml}^{-1}$ of carbendazim and $\mathbf{b} 9.27 \mu \mathrm{g} \mathrm{ml}^{-1}$ of chlorpyrifos

synapses (Sharbide et al. 2011). Organo phosphorous pesticides are known to cause dose- and time-dependent AChE inhibition, and the rate of inhibition differs depending on species and age (Sharbide et al. 2011). The present results show that chlorpyrifos and carbendazim significantly inhibited AchE activity in fish tissue. It is an neurotoxicant and the mode of action is irreversible binding to an serine hydroxyl group in acetylcholine esterase through cholinergic over-stimulation (Ozcan Oruc 2010).

Glutathione plays an important role in the detoxification and excretion of xenobiotics (Palanikumar et al. 2012b). Glutathione depletion is considered a biomarker of environmental stress as observed in fish stressed either by chemical or natural pollutants (Venteshwara Rao 2006). The conjugation of electrophilic compounds (or phase I metabolites) with GSH is catalyzed by the glutathione S-transferases (GSTs), a multigene superfamily of dimeric, multifunctional, primarily soluble enzymes. Apart from their essential functions in intracellular transport (heme, bilirubin and bile acids) and the biosynthesis of 
Table 3 Micronuclei frequency in erythrocytes of $C$. chanos treated with carbendazim and chlorpyrifos to milkfish $C$. chanos $(n=3)$ $($ Mean $\pm \mathrm{SD})$

\begin{tabular}{lllc}
\hline Toxicants & $\begin{array}{l}\text { Concentration } \\
\left(\mu \mathrm{g}^{-1}\right)\end{array}$ & $\begin{array}{l}\text { No of cells } \\
\text { counted }\end{array}$ & $\begin{array}{l}\text { No of MN/1,000 } \\
\text { cells }\end{array}$ \\
\hline Carbendazim & Control & 3,145 & $1.33 \pm 0.58$ \\
& 2.85 & 2,789 & $6.00 \pm 1.00^{*}$ \\
& 5.45 & 2,658 & $13.00 \pm 1.00^{*}$ \\
& 10.97 & 2,579 & $20.00 \pm 1.00^{*}$ \\
& 20.17 & 2,444 & $22.33 \pm 1.15^{*}$ \\
& 45.31 & 2,190 & $24.33 \pm 0.58^{*}$ \\
Chlorpyrifos & Control & 3,789 & $2.00 \pm 1.00$ \\
& 1.38 & 2,335 & $8.67 \pm 0.58^{*}$ \\
& 2.15 & 2,446 & $17.00 \pm 1.00^{*}$ \\
& 4.53 & 2,412 & $22.67 \pm 0.58^{*}$ \\
& 9.27 & 2,323 & $23.67 \pm 1.15^{*}$ \\
& 18.97 & 2,167 & $27.00 \pm 1.00^{*}$ \\
\hline
\end{tabular}

* Statistically significant from control (one way ANOVA, Dunnet test, $P<0.01$ )

leukotrienes and prostaglandins, a critical role for GSTs is obviously defence against oxidative damage and peroxidative products of DNA and lipids (Henson et al. 2001). The susceptibility of different fish species to chemical carcinogenesis may be modulated by the activity of GST (Yin et al. 2007). The toxicity of many exogenous compounds can be modulated by induction of GSTs (Jourmi et al. 2012). The effects of inducing agents on total hepatic GST activity, measured by CDNB conjugation, have been observed in several fish species (van der Oost et al. 2003). Elevated GST activity may reflect the possibility of better protection against pesticide toxicity and used as biomarker for pollution monitoring (Ozcan Oruc 2010). Several studies reported GST activities to be significantly increased, but in most cases no significant differences were observed between fish from control and polluted sites (Pilarczyk and Correia 2009; Oliva et al. 2010).

Winston and Di Giulio (1991) found elevated rates of idiopathic lesions and neoplasia among fish inhabiting polluted environments to be related to the increased oxidative stress associated with pollutant exposure. Oxygen toxicity is defined as injurious effects due to cytotoxic reactive oxygen species (ROS), also referred to as reactive oxygen intermediates (ROIs), oxygen free radicals or oxyradicals (Winzer et al. 2001; Uttara et al. 2009). These reduction products of molecular oxygen $\left(\mathrm{O}_{2}\right)$ are the superoxide anion radical $\left(\mathrm{O}_{2}^{-} \cdot\right)$, hydrogen peroxide $\left(\mathrm{H}_{2} \mathrm{O}_{2}\right)$ and the hydroxyl radical $\left(\mathrm{OH}^{+}\right)$, an extremely potent oxidant capable of reacting with critical cellular macromolecules, possibly leading to enzyme inactivation, lipid peroxidation (LPO), DNA damage and, ultimately, cell death (Winston and Di Giulio 1991; Gill and Tuteja 2010).
CATs are hematin-containing enzymes that facilitate the removal of hydrogen peroxide $\left(\mathrm{H}_{2} \mathrm{O}_{2}\right)$, which is metabolized to molecular oxygen $\left(\mathrm{O}_{2}\right)$ and water. Unlike some peroxidases that can reduce various lipid peroxides as well as $\mathrm{H}_{2} \mathrm{O}_{2}$, CATs can only reduce $\mathrm{H}_{2} \mathrm{O}_{2}$ (van der Oost et al. 2003). CATs are localized in the peroxisomes of most cells and are involved in fatty acid metabolism; changes in activities may often be difficult to interpret (Filho 1996). Pesticide-induced inhibition of CAT activity has been reported in various studies in fish species. For example, Pandey et al. (2001) reported that endosulfan caused a decrease in CAT activity and Yonar and Sakin (2011) reported that CAT activity was significantly decreased in the blood and tissues of fish exposed to deltamethrin concentrations. From the present results, it can be pointed out that the drop in CAT activity could be explained to the oxidative stress caused by the pollutant exposure.

Lipid peroxidation is the preliminary step of cellular membrane damage caused by pesticides and other xenobiotics (Yonar and Sakin 2011) and LPO is considered to be a significant indicator of oxidative damage of cellular components. Most components of cellular structure and function are likely to be potential targets of oxidative damage, and the most susceptible substrates for autoxidation are polyunsaturated fatty acids of the cell membrane, which undergo rapid peroxidation (Blokhina et al. 2003). The increase in MDA level from the present investigation is most likely attributed to an overproduction of ROS, which could be related to antioxidant enzyme leakage. The induction of elevated ROS production can lead to oxidative injury to important cellular macromolecules such as lipids, proteins, and nucleic acids (Bergamini et al. 2004). Similar to the present results, Monteiro et al. (2006) demonstrated that the exposure to $2 \mathrm{mg} \mathrm{l}^{-1}$ of Folisuper $600 \mathrm{BR} \AA$ for $96 \mathrm{~h}$ induced significant increases in LPO levels of Brycon cephalus.

Many studies on pesticides show differences between active ingredients and their formulations with respect of mutagenicity (Grisolia 2002). From this information it can be assumed that genotoxic events are occurring due to increased toxicity of pesticides in their technical grade (Grisolia 2002). The preliminary results observed form the present investigation in $C$. chanos indicate the clastogenic properties of commercial formulations of chlorpyrifos and carbendazim, which really are getting into the aquatic environment.

$\mathrm{MN}$ can originate during anaphase from lagging acentric chromosome or chromatid fragments caused by misrepair of DNA breaks or unrepaired DNA breaks (Fenech et al. 2003). ROS are highly reactive molecules that can disturb the homeostasis of the intracellular physiological state by reacting with cellular macromolecules including DNA, proteins and lipids. One of the advantages of MN assay is 
that it can be used for assessing the DNA damage in many tissues from the same animal and for comparing their responses under identical treatment conditions (Ali et al. 2009). From the present results it can be inferred that the fluctuation in antioxidant enzyme responses may lead to DNA damage, eventually causing micronuclei formation. However, regarding $C$. chanos, the exact mechanism and relationship between micronuclei formation and biochemical enzymes' response deserve further investigation.

In the present study, both the xenobiotics induced significantly higher number of MN formation that increased with concentrations at $96 \mathrm{~h}$. Al-Sabti and Metcalfe (1995) demonstrated that maximal micronucleus induction normally occurred at 1-5 days post-exposure, which agrees with our results. Ali et al. (2009) reported a dose-dependent increase in $\mathrm{MN}$ formation coinciding with the present results. MN assay has also opened a broad perspective in aquatic toxicology, as fish erythrocytes are constantly being exposed to environmental pollutants.

\section{Conclusion}

In conclusion, our data confirm that chlorpyrifos and carbendazim induce similar biochemical changes in milkfish $C$. chanos. In our study, we found that both chlorpyrifos and carbendazim induce clastogenic response (micronuclei formation) with increasing pesticide concentrations. This study showed that chlorpyrifos and carbendazim induced alterations in the activity of antioxidant enzymes and could interfere with nuclear materials and induce clastogenicity. Detailed investigations are required at this stage to correlate the relationship between micronuclei formation and biochemical enzyme responses. Moreover, effects of organophosphate pesticides on marine organisms are not fully understood. The present results show the importance and the effect of pesticides on the natural ecosystem with the alarming rise in pollution over the years. The present study findings help to understand the risk of chlorpyrifos and carbendazim in biochemical enzyme response. Thus, this is the first in vivo study on the action of an organophosphorus pesticide chlorpyrifos and carbendazim on the lipid peroxidation, acetylcholine esterase, catalase, glutathione s-transferase together with cytotoxicity in $C$. chanos. Detailed investigation on sublethal toxicity, bioenergetics, biochemical enzyme response, MN identification and DNA damage index for chlorpyrifos and carbendazim in $C$. chanos needs to be conducted.

Acknowledgments The authors thank IITM, Chennai for providing GC-MS facilities. One of them, Mr.L.Palanikumar, sincerely thanks MoES-ICMAM for fellowship.

\section{References}

Aired TA (2005) Short-term effects of carbendazim on the gross and microscopic features of the testes of Japanese quails (Coturnix coturnix japonica). Anat Embryol (Berl) 210:43-49

Ali D, Nagpure NS, Kumar S, Kumar R, Kushwaha B, Lakra WS (2009) Assessment of genotoxic and mutagenic effects of chlorpyrifos in freshwater fish Channa punctatus (Bloch) using micronucleus assay and alkaline single-cell gel electrophoresis. Food Chem Toxicol 47:650-656

Al-Sabti K, Metcalfe CD (1995) Fish micronuclei for assessing genotoxicity in water. Mutat Res 343:121-135

APHA/AWWA/WEF (1998). Standard methods for the examination of water and wastewater, 20th edn. American Public Health Association, Washington DC, p 1220

ASTM (1997) Standard guide for conducting acute toxicity tests on test materials with fishes, macroinvertebrates, and amphibians. Method E729-96. Annual book of ASTM standards, vol 11.04. American Society for Testing and Materials, West Conshohocken

Bainy ACD, Saito E, Carvalho PSM, Junqueira VBC (1996) Oxidative stress in gill, erythrocytes, liver and kidney of Nile tilapia (Oreochromis niloticus) from a polluted site. Aquat Toxicol 34:151-162

Bergamini CM, Gambetti S, Dondi A, Cervellati C (2004) Oxygen, reactive oxygen species and tissue damage. Curr Pharm Des 10:1611-1626

Beutler E (1982). Catalase. In: Beutler E (ed) Red cell metabolism, a manual of biochemical methods. Grune and Stratton Inc., pp 105-106

Binukumari S, Subhisha MC (2010) Haematological responses in a freshwater fish Oreochromis mossambicus exposed to chlorpyrifos. Ekologia 10:83-88

Blokhina O, Virolainen E, Fegerstedt KV (2003) Antioxidants, oxidative damage and oxygen deprivation stress: a review. Ann Bot 91:174-194

Cavas T, Ergene-Gozukara S (2005) Micronucleus test in fish cells: a bioassay for in situ monitoring of genotoxic pollution in the marine environment. Environ Mol Mutagen 46:64-70

Chindah AC, Sikoki FD, Vincent-Akpu I (2004) Toxicity of an organophosphate pesticide (chlorpyriphos) on a common Niger Delta wetland fish Tilapia guineensis (Blecker 1862). J Appl Sci Environ Manage 8:11-17

Dyk JSV, Pletschke B (2011) Review on the use of enzymes for the detection of organochlorine, organophosphate and carbamate pesticides in the environment. Chemosphere 82:291-307

Ellman GL, Courtney KO, Andres V, Featherstone RM (1961) A new and rapid colorimetric determination of acetylcholinesterase activity. Biochem Pharmacol 7:88-95

Environment Canada (1998) Biological test method: toxicity tests using early life stages of salmonid fish (rainbow trout), Report EPS $1 /$ RM/28, 2nd edn. Ottawa, p 105

Fenech M, Chang WP, Kirsch-Volders M, Holland N, Bonassi S, Zeiger E (2003) HUMN project: detailed description of the scoring criteria for the cytokinesis-block micronucleus assay using isolated human lymphocyte cultures. Mutat Res 534:65-75

Ferreira ALG, Loureiro S, Soares AMVM (2008) Toxicity prediction of binary combinations of cadmium, carbendazim and low dissolved oxygen on Daphnia magna. Aquat Toxicol 89:28-39

Filho DW (1996) Fish antioxidant defenses-a comparative approach. Braz J Med Biol Res 29:1735-1742

Finney DJ (1971) Probit analysis. University Press, Great Britain, p 333

Gill SS, Tuteja N (2010) Reactive oxygen species and antioxidant machinery in abiotic stress tolerance in crop plants. Plant Physiol Biochem 48:909-930 
Grisolia CK (2002) A comparison between mouse and fish micronucleus test using cyclophosphamide, mitomycin $\mathrm{C}$ and various pesticides. Mutat Res 518:145-150

Gul A (2005) Investigation of acute toxicity of chlorpyriphos on Nile tilapia (Oreochromis niloticus) larvae. Chemosphere 59:163-166

Henson KL, Stauffer G, Gallagher EP (2001) Induction of glutathione S-transferase activity and protein expression in brown bullhead (Ameiurus nebulosus) liver by ethoxyquin. Toxicol Sci 62:54-60

Jourmi LE, Amine A, Alaoui MM, Lazar S, Hmyene A, Antri SE (2012) Assessment of water quality in coastal environments of mohammedia applying responses of biochemical biomarkers in the brown mussel Perna perna. IJCSI Int J Comp Sci 9:505-510

Kavitha P, Rao JV (2007) Oxidative stress and locomotor behaviour response as biomarkers for assessing recovery status of mosquito fish, Gambusia affinis after lethal effect of an organophosphate pesticide, monocrotophos. Pest Biochem Physiol 87:182-188

Khare A, Singh S, Srivastava K (2000) Malathion induced biochemical changes in the kidney of freshwater fish C. batrachus. J Ecotoxicol Environ Monit 10:11-14

Lakra WS, Nagpure NS (2009) Genotoxicological studies in fishes: a review. Ind J Ani Sci 79:93-98

Lowry OH, Rosenbrough NJ, Farr AL, Randall RJ (1951) Protein measurement with the folin-phenol reagent. J Biol Chem 193:265-275

Magesh S, Kumaraguru AK (2006) Acute toxicity of endosulfan to milkfish, Chanos chanos, of the southeast coast of India. Bull Environ Contam Toxicol 76:622-628

Monteiro DA, Almeida JA, Rantin FT, Kalinin AL (2006) Oxidative stress biomarkers in the freshwater characid fish, $\mathrm{Br}$ ycon cephal us, exposed to organophosphorus insecticide Folisuper 600 (methyl parathion). Comp Biochem Physiol C 143:141-149

Norppa H, Falck GCM (2003) What do human micronuclei contain? Mutagenesis 18:221-233

OECD (1993) OECD guidelines for testing of chemicals. OECD, Paris

Oliva M, Gonzalez L, deCanales M, Gravato C, Guilhermino L, Perales JA (2010) Biochemical effects and polycyclic aromatic hydrocarbons (PAHs) in senegal sole (Solea senegalensis) from a Huelva estuary (SWSpain). Ecotoxicol Environ Saf 73:1843-1851

Ozcan Oruc E (2010) Oxidative stress, steroid hormone concentrations and acetylcholinesterase activity in Oreochromis niloticus exposed to chlorpyrifos. Pest Biochem Physiol 96:160-166

Palanikumar L, Kumaraguru AK, Ramakritinan CM, Anand M (2012a) Genotoxic assessment of anthracene and benzo [a] pyrene to milkfish Chanos chanos. Tox Env Chem 94:350-363

Palanikumar L, Kumaraguru AK, Ramakritinan CM, Anand M (2012b) Biochemical response of anthracene and benzo [a] pyrene in milkfish Chanos chanos. Ecotoxicol Environ Saf 75:187-197

Pandey S, Ahmad I, Parvez S, Bin-Hafeez B, Haque R, Raisuddin S (2001) Effect of endosulfan on antioxidants of fresh water fish Channa punctatus bloch: 1. Protection against lipid peroxidation in liver by copper pre-exposure. Arch Environ Contam Toxicol 41:345-352

Pandey S, Kumar R, Sharma S, Nagpure NS, Srivatava SK, Verma MS (2005) Acute toxicity bioassay of mercuric chloride and malathion on air breathing fish Channa punctatus (Bloch). Ecotoxicol Environ Saf 61:114-120

Pilarczyk JK, Correia AD (2009) Biochemical response in gilthead seabream (Sparus aurata) to in vivo exposure to pyrene and fluorine. J Exp Mar Biol Ecol 372:49-57

Rao JV, Rani CHS, Kavitha P, Rao RN, Madhavendra SS (2003) Toxicity of chlorpyrifos to the fish Oreochromis mossambicus. Bull Environ Contam Toxicol 70:985-992
Rico A, Waichman AV, Geber-Correa R, Van den Brink PJ (2011) Effects of malathion and carbendazim on Amazonian freshwater organisms: comparison of tropical and temperate species sensitivity distributions. Ecotoxicology 20:625-634

Sharbide AA, Metkari V, Patode P (2011) Effect of diazinon on acetylcholinestrase activity and lipid peroxidation of Poecilia reticulate. Res J Environ Toxicol 5:152-161

Sprague JB (1973). The ABCs of pollutant bioassay using fish. In: Cairns J, Dickson DL (eds), Biological methods for assessment of water quality. ASTM Special Technical Publication 528:6-30

Srivastava VK, Singh A (2001) Studies of seasonal variation in toxicity of frequently used commercial organophosphate, carbamate and synthetic pyrethroid pesticides against freshwater fish Channa punctatus and behavioural responses to treated fish. Malays Appl Biol 30:17-23

Tilak KS, Veeraiah K, Koteswara Rao D (2005) Biochemical changes induced by chlorpyriphos, an organophosphate compound in sublethal concentration of the freshwater fish Catla catla, Labeo rohita and Cirrhinus mrigala. J Environ Biol 26:341-347

Tripathi G, Shasmal J (2011) Concentration related responses of chlorpyriphos in antioxidant, anaerobic and protein synthesizing machinery of the freshwater fish, Heteropneustes fossilis. Pest Biochem Physiol 99:215-220

US EPA (Environmental Protection Agency) (1994) US EPA toxicity data analysis software. EMSL, Cincinnati

Uttara B, Singh AV, Zamboni P, Mahajan RT (2009) Oxidative stress and neurodegenerative diseases: a review of upstream and downstream antioxidant therapeutic options. Curr Neuropharmacol 7:65-74

Van Der Oost R, Beyer J, Vermeulen NPE (2003) Fish bioaccumulation and biomarkers in environmental risk assessment: a review. Environ Toxicol Pharm 13:57-149

Venkataramana GV, Sandhya Rani PN, Murthy PS (2006) Impact of malathion on the biochemical parameters of gobiid fish, Glossogobius giuris (Ham). J Environ Biol 27:119-122

Venkateswara Rao J (2004) Effects of monocrotophos and its analogs in acetylcholinesterase activity's inhibition and its pattern of recovery on euryhaline fish, Oreochromis mossambicus. Ecotoxicol Environ Saf 59:217-222

Venteshwara Rao V (2006) Sublethal effects of an organophosphorus insecticide (RPR-II) on biochemical parameters of tilapia, Oreochromis mossambicus. Comp Biochem Physiol Part C 143:492-498

Vieira LR, Sousa A, Frasco MF, Lima I, Morgado F, Guilhermino L (2008) Acute effects of benzo(a)pyrene, anthracene and a fuel oil on biomarkers of the common goby Pomatoschistus microps (Teleostei, Gobiidae). Sci Tot Environ 395:87-100

Welsh PG, Lipton J, Mebane CA, Marr JCA (2008) Influence of flowthrough and renewal exposures on the toxicity of copper to rainbow trout. Ecotox Env Saf 69:199-208

Winston GW, Di Giulio RT (1991) Prooxidant and antioxidant mechanisms in aquatic organisms. Aquat Toxicol 19:137-161

Winzer K, Winston GW, Becker W, Van Noorden CJF, Kohler A (2001) Sex-related response to oxidative stress in primary cultured hepatocytes of the European flounder (Platychthys flesus L.). Aquat Toxicol 52:143-155

Yin Y, Jia H, Sun Y, Yu H, Wang X, Wu J, Xue Y (2007) Bioaccumulation and ROS generation in liver of Carassius auratus exposed to phenanthrene. Comp Biochem Physiol 145:288-293

Yonar ME, Sakin F (2011) Ameliorative effect of lycopene on antioxidant status in Cyprinus carpio during pyrethroid deltamethrin exposure. Pest Biochem Physiol 99:226-231 